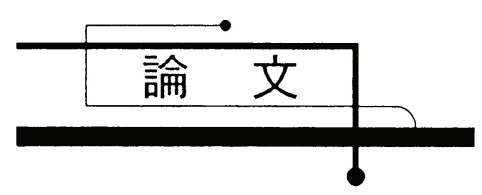

\title{
界面活性剂を用いた泡中アーク放電による カーボンナノチューブの合成*
}

\author{
Study of Carbon Nanotube Synthesis and Dispersion using Arc Discharge \\ in Foam Made with a Surfactant
}

$$
\begin{array}{ll}
\text { 金 勇 —** } \\
\text { KIM Yongil }
\end{array}
$$

\author{
西川英 一**
}

NISHIKAWA Eiichi

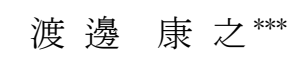

WATANABE Yasuyuki

\begin{abstract}
Relative to the vacuum method, there are drawbacks to the underwater arc discharge method, including weak discharge intensity, low discharge sustainability, and low production volumes of CNTs. Likewise, there are also disadvantages to the arc discharge method in foam as the method requires additional distillation processes to eliminate the beer foam after the production process in spite of its advantages. This study, therefore, investigates an alternative method by replacing the conventional beer foam, used for the discharge location, with foam made from a surfactant (SDS). Experimental results indicated that CNTs can be produced feasibly and efficiently in the same way as in the conventional beer foam method. Further studies were performed to determine whether CNT synthesis and dispersion processes are carried out simultaneously when the CNTs, produced by the arc discharge in SDS foam, are dispersed in the SDS.
\end{abstract}

Keywords: Carbon nanotube, Surfactant, Arc discharge, Foam

\section{1. 緒 言}

カーボンナノチューブ（以下、CNT）は、1991 年に飯島澄男博士によって発見された炭素の新 しい同素体である [1]。CNT は直径数ナノメート ルでありながら, 長さが数マイクロメートルに及 ぶ高アスペクト比（〜数千）をもち, sp2 カーボ ンの強固な化学結合のみから構成されるユニー クな構造により金属材料も凌駕する非常に優れ た機械的強度や, 電気伝導度, 熱伝導性を持ち合 わせており、各種分野への応用が期待されている 物質である。

CNT の合成方法は大きく分けてアーク放電法 [2]、レーザ蒸発法 [3]、化学気相成長法 (CVD 法) [4]の何れかの方法で合成することができる。この うち、アーク放電法は、アーク放電によって陰極
の炭素から放出された電子が、陽極の炭素に衝突 することで、陽極先端の炭素が高温となって蒸発 し、蒸発した炭素原子が再結合することにより CNT が合成される方法であり、特に、直線形状 で高品質な CNT を生成することができるといっ た長所がある。

しかしながら、通常、アーク放電法は、真空中 でアーク放電を行うため、装置構成が複雑であり 高コストといった欠点がある $[3,5]$ 。このため、 簡単な装置構成かつ低コストでカーボンナノチ ューブを合成する方法として、水中でアーク放電 を行う水中アーク放電法が提案された $[6,7]$ 。

水中アーク放電法は真空装置を必要とせず、簡 単な装置構成でカーボンナノチューブを合成す ることが可能なメリットがある。しかしながら、

\footnotetext{
* Received: 28 September 2017 / Accepted: 20 December 2017 / Published online: 18 May 2018

** 東京理科大学工学部電気工学科 干125-8585 東京都葛飾区新宿 6-3-1

TEL: (03)5876-1717Ｅ-mail:kim@rs.tus.ac.jp

*** 諏訪東京理科大学工学部電気電子工学科
} 
水中アーク放電法では、真空中のアーク放電法に 比ベて、アーク放電の放電強度が弱く、放電持続 性が低いなどの欠点があり、単位時間当たりの CNT の生成量が少ないといった問題があった。

そこで、単位時間当たりの CNT の生成量を増 加す心゙く、放電強度と放電持続性を高めるために、 放電環境を真空中と水中の中間の環境である、泡 中アーク放電法が提案された [8]。

泡中アーク放電法のメリットは、真空装置を用 いず放電環境を泡中とする簡単な装置構成であ り、放電環境が水中と比べて真空中の環境に近い ため、放電強度や放電持続性が水中に比べて格段 に良好であり、結晶性の高いCNT を簡単に合成 することが可能である。しかしながら、泡中アー ク放電法では、放電環境の泡にビールの泡を用い ており、CNT 合成後にビールの泡を除去するた めの精製作業が必要であった。

他方、一般にアーク放電によって合成された CNT は、ファンデルワールスカにより束（バン ドル）を形成しや寸いため、水や汎用の溶媒には 分散困難である。超音波照射により一部分散する が、水や有機溶媒は CNT を十分に溶媒和できな いため、超音波照射を止めるとすぐにバンドル状 態に戻ってしまうといった問題がある [9]。この ため、CNT を分散するための分散剤として、陰 イオン性界面活性剤のドデシル硫酸ナトリウム （以下「SDS」と略記する）をCNT 溶媒に加え て超音波処理をすることにより、CNT を分散す る方法が知られている [10-13]。

本研究では、泡中アーク放電法の放電場として、 界面活性剂（SDS）の泡を用いることで、CNT の 合成と分散とを一連の工程で簡単に行うことを 目的とした。

\section{2. 実験方法}

本実験では従来法との比較のため、ビールの泡 中と界面活性剤の泡中との、それぞれ異なる環境 でアーク放電を行ない(2.1 節, 2.2 節)、生成物であ る CNT の結晶性について評価するとともに分散 性について評価した。

すなわち、放電後の泡に付着した生成物を採取 し、電子顕微鏡により観察することで、生成物に 含まれる CNT の結晶性や直線性を評価し(3.1 節, 3.2 節)、さらには、放電後の泡を超音波分散する ことで、CNT 分散溶液を作製し、それぞれの分
散性について比較した(3.3 節)。

\section{1 ビールの泡中でのアーク放電実験}

(1)Fig.1 に示すように、電極には陰極、陽極と もに炭素棒を使用し、500ml のビーカーにビール (アサヒスーパードライ, $350 \mathrm{ml}$ )を入れ、ポンプ $(\beta$ 2000 , 定格電圧 $100 \mathrm{~V}$, 定格消費電力 $2.5 \mathrm{~W})$ で空気 を送り込み、ビールの泡を連続的に発生させる。

(2)炭素電極が完全に埋没させるまでビールの 泡を満たした後、直流電源より20V、20A の直流 電圧を印加し、炭素電極間のアーク放電を 30 分 間行った。

(3)通常、泡中のアーク放電では、アーク放電に 伴う急激な温度上昇により泡が膨らみだす。この とき、小さい泡が破裂するとともに泡の表面張力 が作用して、隣接する泡同士が再び合体するため、 放電空間の泡が壊れることなく、泡中でも安定し たアーク放電が可能である。

(4)放電後に、ビールの泡に付着した生成物を採 取し、透過電子顕微鏡により観察した(3.1 節)。他 方、放電後のビールの泡を超音波分散処理するこ とで、分散溶液を作製し、分散溶液中の生成物を 透過電子顕微鏡により観察した(3.3 節)。

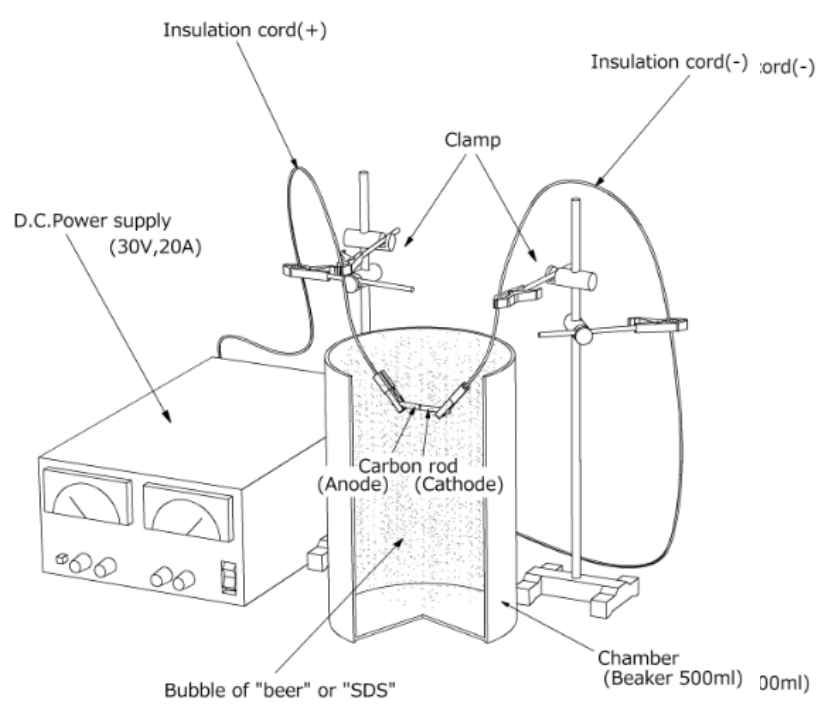

Fig. 1 A schematic of the experimental setup for the arc discharge in foam method. 


\section{2 界面活性剂の泡中でのアーク放電実験}

(1)界面活性剂の泡中アーク放電を行うにあた って、ビールの泡と同等の泡を作製するために、 蒸留水 $100 \mathrm{ml}$ に対し界面活性剂の濃度を調整し て泡の持続性を比較した。

(2)すなわち、蒸留水 $100 \mathrm{cc}$ に対し、ドデシル硫 酸ナトリウム粉末 $0.01 \mathrm{mg}$ を溶解させたものを、 界面活性剂濃度 $0.01 \%$ とし、0.01\%から $0.05 \%$ ま で $0.01 \%$ 刻みで濃度を調整し、 5 種類の界面活性 凨の濃度について、泡立ちと泡の消えやすさを比 較することで界面活性剤の最適な濃度を求めた。

泡の発生は、界面活性剂の溶液中に配置したポ ンプから連続して空気を送り込むことで、界面活 性剂の泡を持続的に発生させた。

(3)Fig.2 に示すように、ビーカー上端までの泡 の上昇時間と、ビーカー上端から $500 \mathrm{cc}$ 目盛り (Fig.3)までの泡の降下時間とをそれぞれ比較し た。 $0.01 \%$ の濃度では他の濃度に比べて、泡の上 昇時間が長く、泡の下降時間が短いことがわかる。

寸なわち、界面活性剂の気泡は、水の濃度が上 がると、相対的に界面活性剂の濃度が下がるため、 時間の経過とともに気泡が壊れやすく気泡の持 続時間が短いためである。

これに対して、界面活性剂の濃度 $0.03 \%$ 以降で は、気泡を生成するための界面活性剤の濃度が相 対的に上がるため、泡の上昇時間が短く、泡の下 降時間が長いことがわかる。界面活性剤の濃度 0.03\%以降では泡の持続時間は変わらないことか ら、界面活性剂濃度 $0.03 \%$ の溶液を用いることと した。

(4)Fig.3(a) に示すように、ビーカーに濃度を $0.03 \%$ に調整した界面活性剂溶液を入れ、炭素電 極が完全に埋没させるまでビールの泡を満たし、

Fig.3(b)に示すように、直流電源より 20V、20A の直流電圧を印加し、「2.1 ビール泡中でのアーク 放電実験」と同様の条件下、炭素電極間のアーク 放電を 30 分間行った。

(5)放電後に、ビールの泡中でアーク放電を行う 場合と同様に、界面活性剂の泡に付着した生成物 を TEM 観察用のマイクログリッドで採取し、生 成物の状態（CNT の結晶性や直線性）を観察し た(3.2 節)。

他方、界面活性剂の泡を超音波分散して分散溶 液を作製し、溶液の分散性、および溶液中の CNT の分散性の評価を行った(3.3 節)。

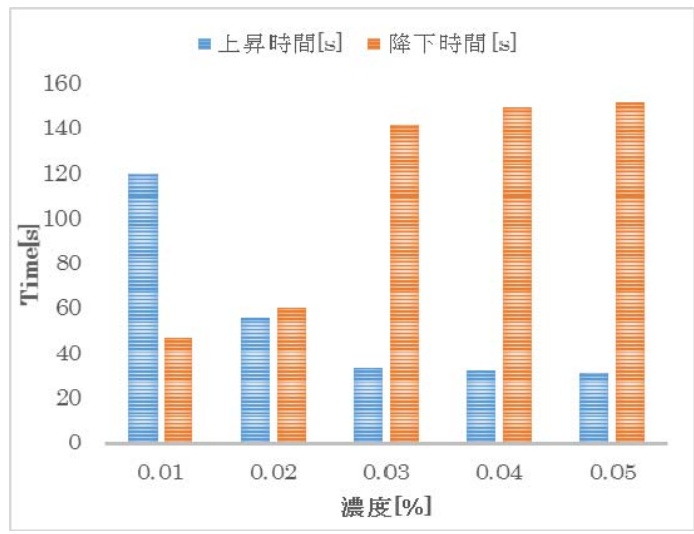

Fig. 2 Comparisons of foam sustainability due to differences in the density of surfactants (blue: rising time [s], orange: receding time [s]).

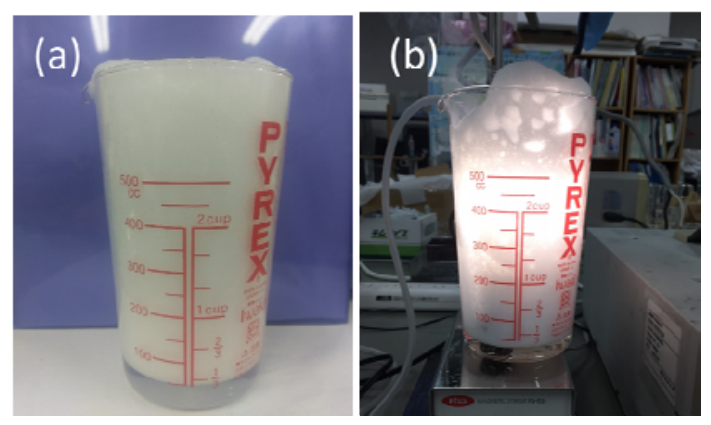

Fig. 3 Image showing foam in a $0.03 \%$ concentration of surfactant. (a)surfactant foam (b)arc discharge in surfactant foam

\section{3. 実験結果及び考察}

(1)放電後の生成物の評価としては、まず、ビー ルの泡と界面活性剤の泡とに付着したそれぞれ の生成物を透過電子顕微鏡（TEM）により観察し た。(アーク放電 $\rightarrow$ 泡の表面から生成物採取 $\rightarrow$ TEM 観察)

これにより、放電直後のそれぞれの生成物を観 察して結晶性などの違いを比較した(3.1 節, 3.2 節)。

(2)次に、ビールの泡と界面活性剤の泡をそれぞ れ超音波洗浄機（FU-2H、発振周波数 $38 \mathrm{kHz}$ ) に より分散処理をかけ分散溶液を作製し、これらの 
分散溶液を 72 時間経過後に目視により分散性を 比較するとともに、電子顕微鏡により観察した

(アーク放電 $\rightarrow$ 超音波処理 $\rightarrow$ 分散液から生成物 の採取 $\rightarrow \mathrm{T} \mathrm{EM}$ 観察）（3.3 節）。

\section{1 ビール泡に付着した生成物の観察}

ビール泡中アーク放電後の、ビール泡に付着し た生成物の TEM 画像を Fig.4(a)(b) に示す。

Fig.4(a)に示すように、直径 $30 \mathrm{~nm}$ 前後、長さ 400nm ほどの直線状の CNT が観察された。それ ぞれの CNT は、ファンデルワールスカにより互 いにバンドルを形成していることがわかる。さら に Fig.4(a)の枠部分を拡大して観察したところ、

Fig.4(b)に示すように、結晶性および直線性の良 好な CNT が観察された。
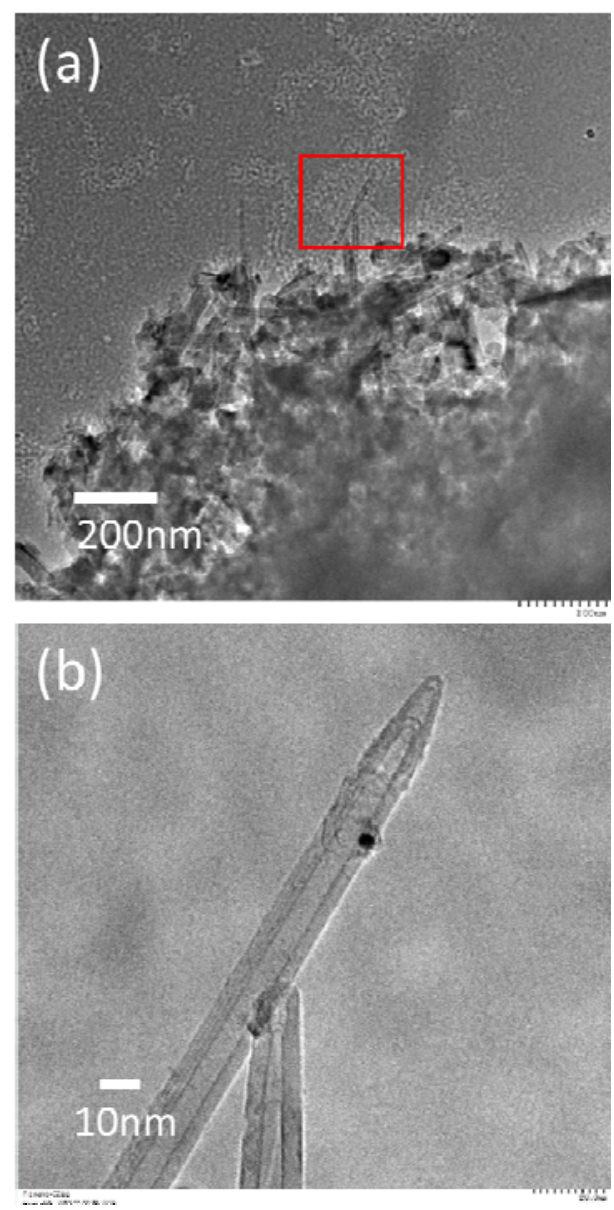

Fig. 4 TEM images of CNTs produced in beer foam.

\section{2 界面活性剂泡に付着した生成物の観察}

次に、界面活性剂泡中アーク放電において合成 した生成物（界面活性剂泡に付着した生成物）を Fig.5(a)(b) に示す。

ビール泡中で合成した CNT の TEM 画像と同様 に、界面活性剤の泡に付着した生成物からは、

Fig.5(a) に示すように、CNT が密集した状態で観 察された。さらに Fig.5(a) の枠部分を拡大して観 察したところ、Fig.5(b) に示すように、ビール泡 中と同様に結晶性および直線性の高い CNT が観 察された。このように、ビール中で合成した CNT と SDS 中で合成した CNT でサイズや欠陥等の違 いは見られず、界面活性剤の泡中においても、ビ ールの泡中と同様に直線性および結晶性が高い CNT が観察された。
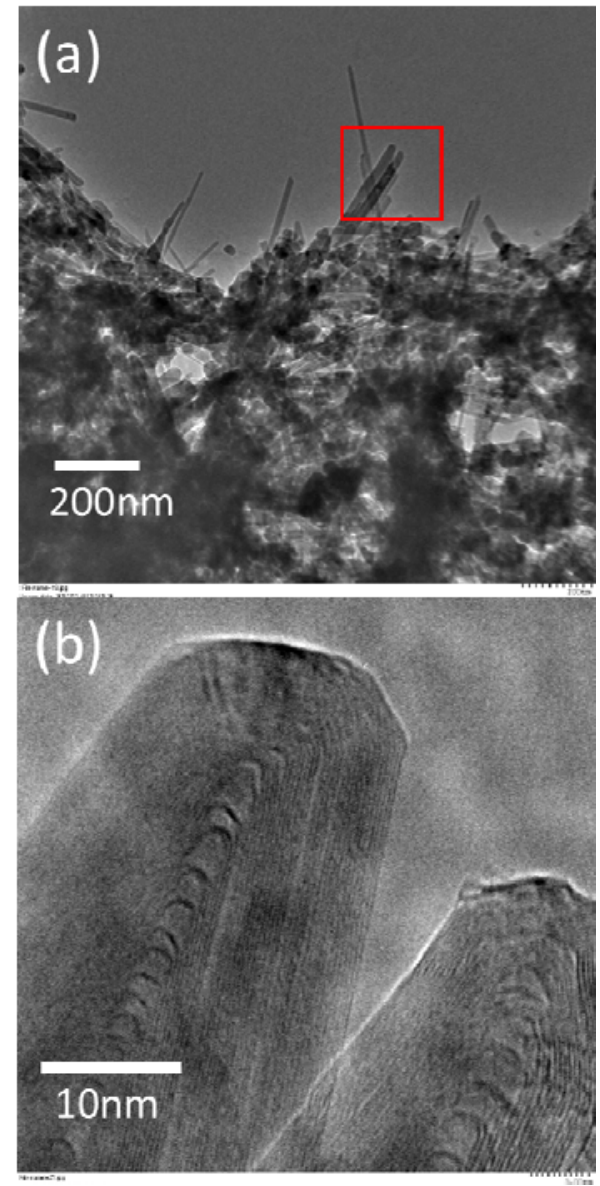

Fig. 5 TEM images of CNTs produced in surfactant foam. 


\section{3 超音波処理後における分散溶液の分散性}

放電後のビール泡と界面活性剂泡とを、それぞ れ超音波洗浄機により 1 時間の超音波分散処理 を行ない、それぞれの分散溶液を作製した後、さ らに 72 時間経過させることで、分散溶液中の生 成物の沈殿具合から分散性を比較した（Fig.6）。

超音波処理後のビール泡の分散溶液は、

Fig.6(a) に示すように、72 時間経過後に観察する と、ビーカーの底部に生成物が沈殿しており、生 成物の分散が不十分であった。

他方、超音波処理後の界面活性剂泡の分散溶液 は、Fig.6(b) に示すように、72 時間を経過しても 生成物が沈殿することがなく、液体が均一な黒色 を維持しており、生成物が液体中に均一に分散さ れていた。

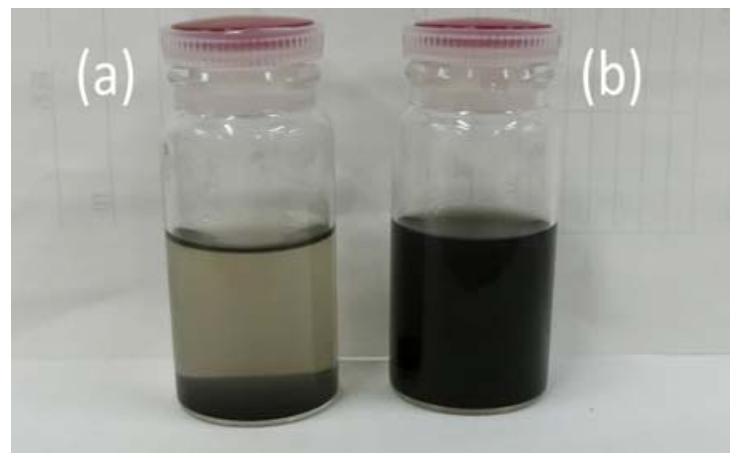

Fig. 6 Samples after ultrasonic dispersion

(a)beer foam (b) Surfactant foam.

さらに、それぞれの分散溶液を TEM 観察した ものを Fig.7(a)(b) に示す。

Fig.7(a) に示すように、ビール泡中でアーク放 電を行った分散溶液中の生成物からは、CNT が 凝集したものが多数観察された。これにより、ビ 一ル泡中の生成物は、超音波分散をかけても充分 な分散が困難であることがわかる。

他方、Fig.7(b) に示すように、界面活性剤の泡 中でアーク放電を行った分散溶液中の生成物か らは、個々の CNT やフラーレンが多数分離した 状態で観察された。これは、界面活性剤の泡を超 音波分散処理することにより、生成物の分散が良 好に行われていることを示す。

すなわち、ビールの泡の主成分は水であるため、 疎水性をもつ CNT は分散しにくいが、界面活性 剤の泡は、界面活性剤の作用により CNT が親水
性をもつことで分散が容易となったことと考え られる。しかしながら、Fig.7(b) に示すように、 CNT のみならず多数のフラーレンが観察される ことから、アーク放電の電圧・電流を制御するこ とにより、CNT がより多く生成される条件を見 つける必要がある。

このように、分散処理後のそれぞれの分散溶液 を TEM により観察すると、ビール泡の分散溶液 においては、CNT の分散が不十分であり、界面 活性剂泡の分散溶液においては、CNT が分散さ れていることがわかった。
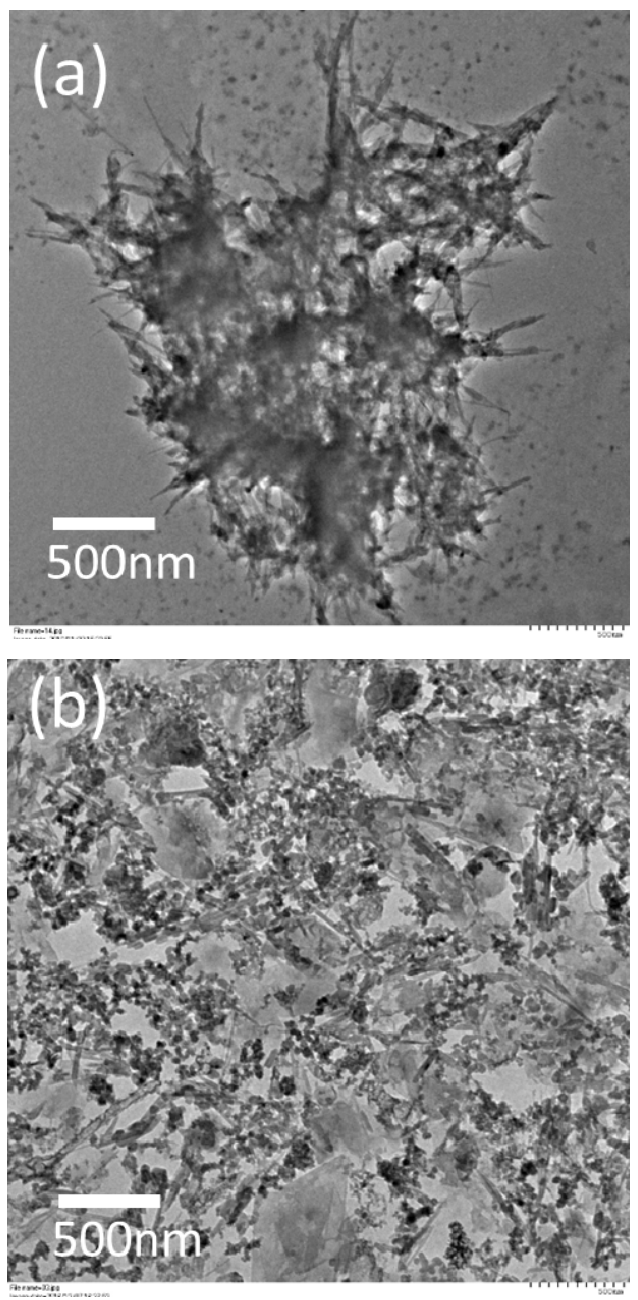

Fig. 7 TEM images showing products after ultrasonic dispersion processing in (a) beer foam and (b) surfactant. 


\section{4. まとめ}

界面活性剤 SDS（ドデシル硫酸ナトリウム）を 蒸留水に溶解し、0.03\%に濃度を調整した界面活 性剂泡中でアーク放電を行うことで、界面活性剤 の泡中においても、ビール中で合成した CNT と SDS 中で合成した CNT でサイズや欠陥等の違い は見られず、ビールの泡中と同様に直線性および 結晶性が高い CNT が合成することができた。

さらには、アーク放電後の界面活性剤の泡を超 音波分散処理することにより、CNT の分散を容 易に行うことができた。

よって、界面活性剤の泡中でアーク放電を行な い超音波分散処理を行うことにより、CNT の合 成と分散とを一連の工程で行うことが可能であ り、簡単な方法で結晶性および直線性の高い良質 な CNT を合成し分散させることが可能である。

また、従来のビールの泡中で生成した CNT は、 ビールの泡の成分が付着するため、そのままの状 態でサンプルを保管すると、数日後にはカビが発 生するため、常温下での保存が困難であるが、こ れに対して、界面活性剤の泡中で生成した CNT は、常温下において数日間の保存をしてもサンプ ルの CNT に変化が生じることはなく長期間にわ たり安定して保存が可能であった。このことから、 界面活性剤の CNT 分散溶液を用いて CNT 薄膜の 作製などに応用した場合にも、カビなどが薄膜に 発生することなく、長期間にわたり安定した CNT 薄膜を維持することが可能である。

以上のように、本実験により、界面活性剤の泡 を用いることにより、CNT の合成と分散とを同 時に行うことが可能であることがわかった。しか しながら、泡中でのアーク放電では、CNT のみ ならずフラーレンなどのナノカーボンも同時に 合成されるため、アーク放電の電圧・電流值によ る CNT の生成量の定量的な分布を確認すること が今後の課題である。

\section{謝 辞}

本論文では、数々の実験を行ってくれた西川研 究室の新堀君と関君に感謝の意を表する。

\section{参考文献}

[1] Iijima. S, Nature, Helical microtubules of graphitic carbon, Vol. 354, 56 (1991).

[2] Kroto. H. W, Heath. J. R., O’Brien. S. C., Curl. R. F., Smalley. R. E., C60: Buckminsterfullerene, Nature, Vol. 318 (1985).

[3] Thess. A et al., Science, Crystalline Ropes of Metallic Carbon Nanotubes, Vol.273, 483 (1996).

[4] Cassell A. M., Raymakers J. A., J. Kong, and H. J. Dai, Large Scale CVD Synthesis of Single-Walled Carbon Nanotubes, J. Phys. Chem. B 103 (1999) 6484.

[5] Kratschmer. W, Lamb. L.D, Fostiropoulos. K, and Huffman. D.R., Solid C60: a new form of carbon, Nature, Vol. 347,354 (1990).

[6] Sano. N, Wang. H, Chhowalla. M, Alexandrou. I and G. A. J. Amaratunga, Synthesis of carbon 'onions' in water, Nature, Vol. 414, 506 (2001).

[7] Kim.Y, Nishikawa. E, Kioka. T, Preparation of Carbon Nanotubes by Low Electric Current Arc Discharge in Water, The Surface Finishing Society of Japan, Vol. 60 (5), 349 (2009).

[8] Kim.Y, Nishikawa. E, Kioka. T, Multiwalled Carbon Nanotubes Produced by Direct-Current Arc Discharge in Foam, e-JSSNT, Vol. 6, 167 (2008)

[9] Dyke. C.A and Tour J.M, Covalent Functionalization of Single-Walled Carbon Nanotubes for Materials Applications, J. Phys. Chem. A, Vol. 108, 11151 (2004).

[10] O'Connell. M.J., Bachilo. S.M., Huffman. C.B., Moore. V.C., Strano. M.S., Haroz. E.H., Rialon. K.L., Boul. P.J., Noon. W.H., Kittrell. C., Ma. J., Haugel. R.H., Weisman R.B., and Smalley R.E., Band gap fluorescence from individual single-walled carbon nanotubes, Science, Vol. 297, 593 (2002).

[11] Islam. M.F, Rojas. E., D.M. Bergey, A.T. Johnson, and A.G. Yodh, High Weight Fraction Surfactant Solubilization of Single-Wall Carbon Nanotubes in Water, Nano Lett., Vol. 3, 269 (2003).

[12] Richard. C, Balavonia. F, Schultz. P, T. W. Ebbesen, and C. Mioskowski, Supramolecular Self-Assembly of Lipid Derivatives on Carbon Nanotubes, Science, Vol. 300, 775 (2003).

[13] Duesberg. G.S.B, Muster. M.J, Philipp. G. and Roth. S., Separation of carbon nanotubes by size exclusion chromatography, Chem. Commun., 435 (1998). 